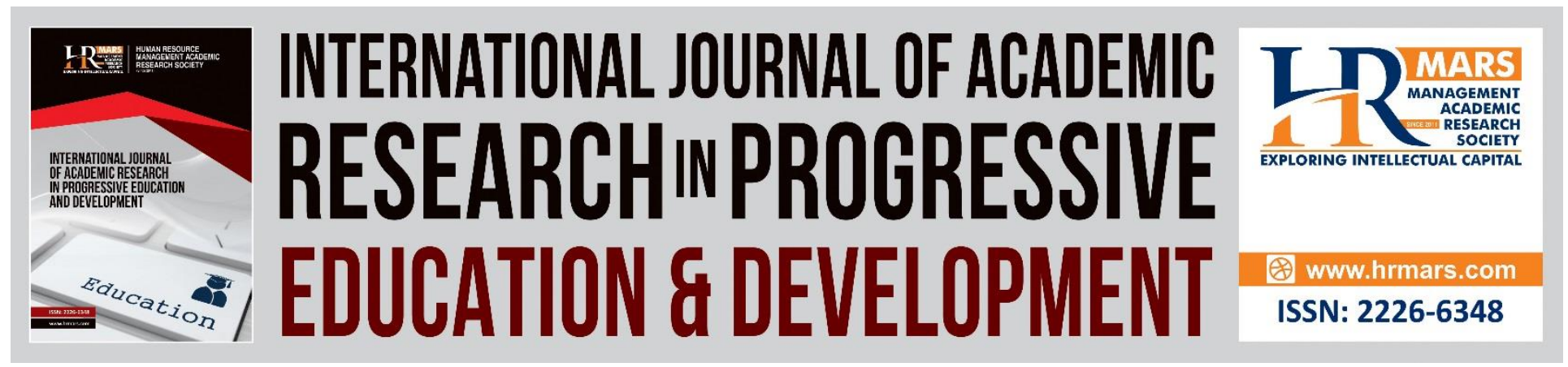

\title{
Influence of Teachers' Attitude towards Teaching Profession on Under Graduate Non-Education Students Perception of Teacher Education
}

ODIKE, Maryrose \& NNAEKWE, Uchenna Kingsley

To Link this Article: http://dx.doi.org/10.6007/IJARPED/v7-i4/4833

DOI: $10.6007 /$ IJARPED/v7-i4/4833

Received: 17 Sept 2018, Revised: 28 October 2018, Accepted: 03 Nov 2018

Published Online: 10 Nov 2018

In-Text Citation: (Odike \& Nnaekwe, 2018)

To Cite this Article: Odike, M., \& Nnaekwe, U. K. (2018). Influence Of Teachers' Attitude Towards Teaching Profession On Under Graduate Non-Education Students Perception Of Teacher Education. International Journal Of Academic Research In Progressive Education And Development, 7(4), 67-79.

\section{Copyright: (C) 2018 The Author(s)}

Published by Human Resource Management Academic Research Society (www.hrmars.com)

This article is published under the Creative Commons Attribution (CC BY 4.0) license. Anyone may reproduce, distribute, translate and create derivative works of this article (for both commercial and non-commercial purposes), subject to full attribution to the original publication and authors. The full terms of this license may be seen at: http://creativecommons.org/licences/by/4.0/legalcode

Vol. 7, No. 4, 2018, Pg. 67 - 79

Full Terms \& Conditions of access and use can be found at http://hrmars.com/index.php/pages/detail/publication-ethics 


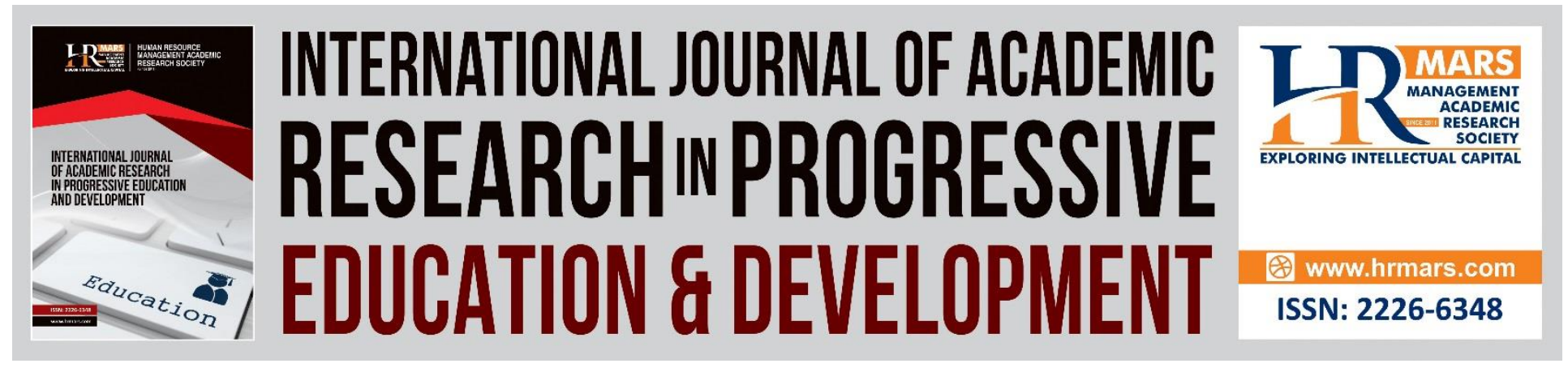

\title{
Influence of Teachers' Attitude towards Teaching Profession on Under Graduate Non-Education Students Perception of Teacher Education
}

\author{
ODIKE, Maryrose Ph.D.
}

Department of Science and Vocational Education, Godfrey Okoye University, Enugu

NNAEKWE, Uchenna Kingsley

Department of Science and Vocational Education, Godfrey Okoye University, Enugu

Email: unnaekwe@gouni.edu.ng

\begin{abstract}
Teacher's attitude towards teaching profession can either encourage or discourage students from being desirous of engaging in teaching profession. The major purpose of this study was to find out the influence of some teachers' attitudes towards teaching profession on the perception of non-education under graduate students of private universities in Enugu State Metropolis of teaching profession. The population of the study consisted of all the 3641 non- education undergraduate students of both Godfrey Okoye and Caritas universities in Enugu. The sample size of 360 was used for the study. The sample size was determined using Yamane's (1964) statistical formula. Based on that, 360 copies of questionnaire were distributed to the respondents. The data collected were analysed using statistical package for social sciences (SPSS). The findings among others include that-incompetency of some teachers in delivering their lessons, demanding money from students to pass them in their examination the issue of befriending female students by some male teachers influence undergraduate students' perception of teaching profession negatively. It was concluded among other things some teachers' negative attitude toward teaching profession and unethical behaviour exhibited by some teachers contributed a great extent to the poor perception of undergraduate students towards teaching profession. The recommendations made includes: that the teachers should be proud of their profession, prepare their lesson very well to show mastery of their subject matters and exhibit positive attitudes towards their profession so as to encourage students to be desirous of teaching profession.
\end{abstract}

Keywords: Teacher, Teaching Profession, Teacher Education, Non-Education-Undergraduate Students and Attitude 


\section{Introduction}

Teaching is defined by Teachers Registration Council (2005) as" a systematic rational and organized process of transmitting knowledge, attitudes and skills in accordance with professional principles." The essence of teaching is to influence learners to make desirable changes in their behaviour that contribute to better living. Effective teaching contributes to the individual' understanding, helps him to improve his abilities, and develops in him more desirable aptitudes. According to Obayi, (2009) in Odike (2013), a person who had undergone approved professional training in education at appropriate levels capable of imparting knowledge, attitudes and skills to the learners is a professionally trained teacher.

Teachers are categorized into four classes as follows: A - Class: Holders of PhD in Education or PhD in other fields plus Education (e.g. P.G.D.E. and N.C.E.); 2. B - Class: Holders of Masters Degree in Education or Masters in other field plus Education (e.g. P.G.D.E. and N.C.E.); 3. C - Class: Holders of Bachelor in Education or Bachelor in other fields plus Education (e.g. P.G.D.E. and N.C.E.); 4. D - Class: Holders of Nigeria Certificate in Education (N.C.E.) or equivalent. (Teachers Registration Council of Nigeria (T.R.C.N., 2004) Act No.31 of 1993).

\section{Teaching profession:}

Fadokun (2010), in Usman, Aklahyel, Ibrahim and Adam (2015). a profession refers to an occupation that is dependent upon specialized intellectual study and training, for the provision of skilled service to other members of the society, government and non-governmental agencies for a definite fee or salary. Usman, Aklahyel, Ibrahim and Adam (2015) noted that Teaching profession is one of the most noble and the oldest profession in the history of mankind. According to them, the profession of teaching is the most indomitable profession in the world and history has shown that teachers occupied the position of great honor and influence in their communities. National Policy on Education (2004) state that states that since no education can rise above the quality of its teacher, teacher education should continue to be given major emphasis in all educational planning and development. Furthermore, all teachers in educational institutions from pre-primary to university should be professionally trained. Teacher education programme should be structured to equip teachers for the effective performance of their duties (T.R.C.N., 2004).

\section{Attitude of undergraduates/teachers towards teaching profession}

As defined by Allport (1935) in Elina (2016) "Attitude is a mental or neural state of readiness, organized through experience, exerting a directive or dynamic influence upon individual's response to all objects and situations with which it is related „. Furthermore, attitudes mean the individuals" prevailing tendency to respond favourably or unfavourably to an object, person or group of people, institutions or events" Morris and Maistro, (2005) in Elina (2016). No one is born with any attitudes. Attitudes like interests are learned through life experiences which makes an individual behave towards persons, profession, objects, issues, situations, etc., to which they are related. Attitudes considerably influence one's behavior, accordingly. The individual's attitudes may be positive (favourable) or negative (unfavourable). Kreinter and Kinicki (2007) in Elina (2016), observed that there are three components of attitudes -affective component (feeling or emotion), cognitive component (beliefs or ideas), and psychomotor component (behaviour 
INTERNATIONAL JOURNAL OF ACADEMIC RESEARCH IN PROGRESSIVE EDUCATION AND DEVELOPMENT

Vol. 7, No. 4, 2018, E-ISSN: 2226-6348 ๑ 2018 HRMARS

towards someone or something). If a teacher's attitudes are negative, then, he will not be able to succeed in his profession. The teacher intellectual attitudes, emotional reactions, various habits and personality that includes all these affects the students in terms of academic success, personality , interest, etc.,(Bloom, 1976; Jeans, 1995; Brooks and Sikes, 1997).

\section{Poor attitudes of teachers towards teaching profession in Nigeria}

It has been observed by many researchers including, Lawal, (2012) Usman, Anupama, and Parthy (2014) Aklahyel, Ibrahim and Adam, (2015) and Elina (2016) that teaching profession is not attractive to many Nigerian child. So many factors according to many empirical studies contributed to the unattractiveness of teaching profession in Nigerian. These factors among others include- poor remuneration, teachers' poor conditions of service, irregular payment of salaries, lack of uniform salary scale, poor conditions of schools facilities, unfriendly school environment, low perception of others about the teacher, lack of incentives poor motivation, non-payment of allowances. Others include frequent teacher transfer, transportation problems, and over-crowded classrooms, lack of seriousness on the part of students. All these are among the factors that de-motivate teachers and lower their morale for teaching. Some teachers for lack of job satisfaction tend to be disillusioned about teaching profession and consequently exhibit some unethical behavior.

According to Usman, Aklahyel, Ibrahim and Adam. (2015), Teaching no longer attracts favourable attention from the public and society. The high rate of indiscipline and arrogance exhibited by students and pupils make prospective teachers to develop a wrong perception of teaching profession. Aghenta (1981) in Usman, Aklahyel, Ibrahim and Adam, (2015), opined that teachers are denied kind words and encouragement; their salaries are not regularly paid and allowances are reduced. Education administrators threaten them; students treat them with disrespect while members of the public refuse them sympathy. Consequently, they lack job satisfaction and become frustrated and exhibit behavior that discourages students from developing interest in teaching profession.

The teacher's attitude towards the teaching profession can affect the student's attitudes towards teaching. If teachers have job satisfaction they will exhibit positive attitudes and students will be motivated to aspire to engage in teaching profession. Elina (2016) found out that more qualified teachers seemed to be having more positive attitudes than the less qualified teachers. Similarly, younger teachers appear to possess more positive attitudes towards teaching than older teachers.

Negative attitude of some non-education undergraduate students towards teacher education makes the students of faculty of education feel that they made wrong choice by opting to study education. Non education undergraduate students tend to look down on education undergraduates and they assume that education students are less intelligent. They ridicule them by calling them teachers. Olaitan and Agusiobo (1981) in Odike, (2013) stated that, teaching has been regarded by many as a job which anybody can enter and leave freely without much difficulty or any harm to the educative process. Such teachers who have perceived and accepted teaching as a partial career exhibit negative attitudes towards teaching. Such negative attitude makes such teachers to become disillusioned in teaching subjects assigned to them. This equally can lead to poor performance of students in the various subjects such teachers teach. 
Vol. 7, No. 4, 2018, E-ISSN: 2226-6348 ๑ 2018 HRMARS

Teacher education is a program of study that prepares the recipients for teaching at the secondary and primary schools in Nigeria. Ogunyinka, Okeke and Adedoyin (2015) explain that teacher education, as policies and procedures designed to equip prospective teachers with the knowledge, attitude, behaviour and skills that will enable them perform their functions effectively in the classroom, schools, church/ mosque and the local and wider society.

In this work, the researcher examined the extent to which teachers' attitude towards teaching profession influence the perception of non education undergraduate students of private universities in enugu metropolis students' to teacher education, in preparation for teaching in both primary and secondary schools.

\section{The Purpose of the Study}

The major purpose of this study was to determine the influence of teachers' attitudes to teaching profession on perception of undergraduate Students of the private universities in Enugu metropolis towards Teacher education. Specifically, the study:

1. Determined the extent to which behaviour of some primary and secondary school teachers contributes to non-education under graduate students of the private universities in Enugu Metropolis poor perception of teacher education.

2. Find out the extent to which attitude of primary and secondary school teachers contribute to non-education undergraduate students of the private universities in Enugu Metropolis poor perception of teachers' education.

\section{Research Questions:}

1. To what extent does the attitude of primary and secondary school teachers towards teaching profession contributes to the non-education undergraduates students poor perception of teacher education?

2. To what extent does behaviour of some primary and secondary school teachers contributes to non-education Undergraduates students of the private universities in Enugu Metropolis poor perception of teacher education?

\section{Hypotheses}

The following null hypotheses were postulated for the study

Ho1. There is no difference between the mean responses of male and female non education undergraduate students of the private universities in Enugu metropolis on the extent to which attitude of primary and secondary school teachers towards teaching profession contributes to their poor perception of teacher education.

Ho2. There is no difference between the mean responses of male and female non- education undergraduate students of the private universities in Enugu metropolis on the extent to which behaviour of some primary and secondary school teachers' contributes to their poor perception of teacher education? 


\section{Methodology}

Design of the Study. The design of the study was a descriptive survey. The study covered private universities in Enugu metropolis. The population of the study consisted of 3641 of education undergraduate students of both Godfrey okoye university ugwuomu Nike Enugu and Caritas University Emene, Enugu. A sample size of 360 respondents was drawn from the population. A structured questionnaire constituted the major instruments for this study. The questionnaire was validated by experienced experts in the construction of research instruments in Godfery Okoye University Enugu, and its reliability coefficient was 0.86 . The 360 Copies of questionnaire were administered personally by the researcher and other research assistants. The data analysis was based on the questionnaire returns of 325 out of 360 copies, representing 90 percent. The mean with standard deviation was used to analyse responses for answering the research question.

ANOVA was used for the null hypotheses. The questions were optioned using five point (5) Likert scale type of responses, namely: Very great extent (VGE)=5; Great extent (GE)=4; Undecided (UN) =3; low extent $(\mathrm{LE})=2$; Very low extent $(\mathrm{VLE})=1$

The necessary decision was made according to the degree of limits revealed by the results. For answering the research question, the boundary limits of numbers are presented below, thus
Very great extent (5)
4, 50----5.00; Great extent
(4)
3.50-----4, 49;
Undecided
2.50-----3.49; low extent
1.50-----2.49;

Very low extent

(1) 0, 50----1.49,

\section{Decision rule}

As regards research questionnaire items, any item with mean rating of 3 and above is accepted as a contributing factor while any one below 3 should be rejected.

Reference to the hypothesis, if the critical value of $F$ is less than the calculated value of $F$ reject the null hypothesis if otherwise uphold it.

\section{Results and Discussion \\ Research Questions}

In this section the findings of the study in relationship to the objectives are presented and discussed.

\section{Research Question One}

1. To what extent does attitude of primary and secondary school teachers towards teaching profession contributes to perception of non-education undergraduate students of the private universities in Enugu Metropolis to teacher education.?

This research question was answered using items 1-8 in the questionnaire. The data were presented in the table 1 below. 
Table 1: Mean Ratings and Standard Deviation of Respondents of Students on Primary and secondary schools Teachers' attitude towards teaching profession

\begin{tabular}{|l|l|l|l|l|}
\hline S/N & ITEM & Mean & $\begin{array}{l}\text { Std. } \\
\text { Deviation }\end{array}$ & Decision \\
\hline 1 & $\begin{array}{l}\text { Most teachers discourage their children from } \\
\text { taking up teaching as a profession. }\end{array}$ & 3.7101 & 1.28612 & ACCEPTED \\
\hline 2 & $\begin{array}{l}\text { Most teachers see teaching profession as not } \\
\text { being as prestigious as other professions. }\end{array}$ & 3.7420 & 1.22242 & ACCEPTED \\
\hline 3 & $\begin{array}{l}\text { Most teachers always complain of not receiving } \\
\text { as much salaries as other professionals }\end{array}$ & 3.3681 & 1.37275 & ACCEPTED \\
\hline 4 & $\begin{array}{l}\text { Teachers complain of not being respected by their } \\
\text { students/pupils. }\end{array}$ & 3.2696 & 1.28941 & ACCEPTED \\
\hline 5 & $\begin{array}{l}\text { Some teachers do not attend their classes } \\
\text { regularly. }\end{array}$ & 3.3623 & 1.35083 & ACCEPTED \\
\hline 6 & $\begin{array}{l}\text { Some teachers do not come to schools regularly } \\
\text { Some teachers always complain of not being paid } \\
\text { their salaries } \\
\text { Some teachers complain of not being regarded } \\
\text { by some parents } \\
\text { GRAND MEAN }\end{array}$ & 3.5652 & 1.40678 & ACCEPTED \\
\hline 8 & \begin{tabular}{l} 
Gome \\
\hline
\end{tabular} & 3.3565 & 1.36174 & ACCEPTED \\
\hline
\end{tabular}

The data on table 1 shows the respondents' rating of the attitudes of primary and secondary school teachers towards teaching profession. The questionnaire cluster for the research question on the attitude of primary and secondary school teachers to teaching profession was analyses and the results showed that out of the 8 items 7 items were rated by the respondents as accepted while the remaining 1 item was rejected, with a grand mean of 3.3565 this means that the attitudes of primary and secondary school teachers on teaching profession contribute a great extent to poor perception of non-education undergraduate students in private universities in Enugu metropolis to teacher education.

\section{Research Question Two}

To what extent does behaviour of some secondary and primary school teachers contributes to perception of non-education undergraduate students of the private universities in Enugu metropolis towards Teacher education.

This research question was answered using items 9-18 in the questionnaire. The data were presented in the table 4 below. 
INTERNATIONAL JOURNAL OF ACADEMIC RESEARCH IN PROGRESSIVE EDUCATION AND DEVELOPMENT

Vol. 7, No. 4, 2018, E-ISSN: 2226-6348 @ 2018 HRMARS

Table 2: Mean Ratings and Standard Deviation of Respondents on the teachers' Behaviours.

\begin{tabular}{|c|c|c|c|c|}
\hline $\mathrm{S} / \mathrm{N}$ & ITEMS & Mean & $\begin{array}{l}\text { Std. } \\
\text { Deviation }\end{array}$ & Decision \\
\hline 9 & $\begin{array}{l}\text { Incompetency of some teachers in delivering their } \\
\text { lessons }\end{array}$ & 3.7587 & 1.31705 & ACCEPTED \\
\hline 10 & Mode of dressing of some teachers & 3.4128 & 1.41564 & ACCEPTED \\
\hline 11 & $\begin{array}{l}\text { Inferiority complex of some teachers towards rich } \\
\text { parents of their students. }\end{array}$ & 3.6017 & 1.36431 & ACCEPTED \\
\hline 12 & $\begin{array}{l}\text { Over familiarity of some of teachers with their } \\
\text { students. }\end{array}$ & 3.5291 & 1.36567 & ACCEPTED \\
\hline 13 & $\begin{array}{l}\text { Receiving of gifts from students' parents by some } \\
\text { teachers }\end{array}$ & 3.4797 & 1.36155 & ACCEPTED \\
\hline 14 & Demanding gift from students by some teachers & 3.5349 & 1.29990 & ACCEPTED \\
\hline 15 & $\begin{array}{l}\text { Befriending female students by some male } \\
\text { teachers }\end{array}$ & 3.6715 & 1.34433 & ACCEPTED \\
\hline 16 & $\begin{array}{l}\text { Befriending male students by some female } \\
\text { teachers }\end{array}$ & 3.6192 & 1.33915 & ACCEPTED \\
\hline $\begin{array}{l}17 \\
18\end{array}$ & $\begin{array}{l}\text { Some teachers receive money from students to } \\
\text { pass them during examination. } \\
\text { Some teachers collect money from students to } \\
\text { allow them engage in examination malpractice }\end{array}$ & $\begin{array}{l}3.5348 \\
3.5677\end{array}$ & $\begin{array}{l}1.36155 \\
1.36155 \\
1.3507\end{array}$ & $\begin{array}{l}\text { ACCEPTED } \\
\text { ACCEPTED } \\
\text { ACCEPTED }\end{array}$ \\
\hline
\end{tabular}

The data on table 2 reveals the respondents rating of the extent to which behaviour of some primary and secondary school teachers contributes to poor perception of non-education undergraduate students of the private universities in Enugu metropolis towards Teacher education. The result showed that all the ten identified factors were rated by the respondents as accepted with a grand mean of 3.5677 and standard deviation of 1.3507. None of the items has mean score of less than 3 . This indicates that teachers behaviour contribute to a great extent to poor perception of non-education undergraduates students of private universities in Enugu metropolis to teacher education.

\section{Hypothesis 1}

Ho1. There is no difference between the mean responses of male and female non- education undergraduate students of the Private universities in Enugu metropolis on the extent to which attitude of some primary and secondary school teachers towards teaching profession contributes to the students' poor perception of teacher education. 
INTERNATIONAL JOURNAL OF ACADEMIC RESEARCH IN PROGRESSIVE EDUCATION AND DEVELOPMENT

Vol. 7, No. 4, 2018, E-ISSN: $2226-6348$ @ 2018 HRMARS

Table 3: Table of Mean (M) and standard deviation (SD) of gender on the extent to which attitude of primary and secondary teachers contribute to poor perception of non education undergraduate students to teachers education

\begin{tabular}{lcccc}
\hline $\begin{array}{l}\text { Independent } \\
\text { Variable }\end{array}$ & Gender & Mean(X) & SD & N \\
\hline Gender & Male & 24.46 & 4.50 & 101 \\
& Female & 22.28 & 6.00 & 244
\end{tabular}

Result of mean as shown in table 3 indicated that males have higher mean $(M=24.46, S D=4.50)$ than females $(M=22.28, S D=6.00)$ on the extent to which attitude of primary and secondary school teachers toward teaching profession contribute to poor perception of non-education undergraduate students to teacher education

Table 4: ANOVA table showing the difference between male and female students rating on the extent to which attitude of primary and secondary school teachers toward teaching profession contribute to poor perception of non-education undergraduate students to teacher education.

\begin{tabular}{ccccccc}
\hline Source & SS & df & Mean(sq) & $F$ & Sig & Remark \\
\hline Gender & 335.39 & 1 & 335.92 & $10.41^{* * *}$ & .001 & Reject Ho1 \\
Error & 11050.00 & 343 & 32.22 & & & \\
Total & 11385.39 & 344 & & & \\
Note: ${ }^{* * *}=$ & Significant, $\mathrm{P}=.000, * *$ & Significant, $\mathrm{P}=.01, \mathrm{NS}=$ Not Significant, $\mathrm{P}=>.05$
\end{tabular}

Result of table 4 showed that the mean difference between male and female non education undergraduate students of private universities on the extent to which attitude of primary and secondary school teachers toward teaching profession contribute to non-education undergraduate students' poor perception of teacher education were statistically significant, $F$ (1, $343)=10.41, p<.001$, therefore, the null hypothesis which states that there is no difference between the mean responses was rejected.

\section{Hypothesis 2}

Ho2. There is no difference between the mean responses of male and female non- education undergraduates students of the private universities in Enugu metropolis on the extent to which behaviour of some primary and secondary school teachers contributes to their poor perception of teacher education. 
Table 5: Table of Mean (M) and standard deviation (SD) of gender on the extent to which behaviour of some primary and secondary school teachers contributes to non-education undergraduate students' of private universities in Enugu Metropolis poor perception of teacher education.

\begin{tabular}{lllll}
\hline $\begin{array}{l}\text { Independent } \\
\text { Variable }\end{array}$ & Levels & Mean(M) & SD & $\mathrm{N}$ \\
\hline
\end{tabular}

$\begin{array}{ccccc}\text { Gender } & \text { Male } & 27.75 & 7.64 & 101 \\ & \text { Female } & 28.93 & 7.09 & 244\end{array}$

Result of mean in table 5 showed that females have higher mean $(M=28.93, S D=7.09)$ than males $(M=27.75, S D=7.64)$ on the extent to which behaviour of some primary and secondary school teachers contributes to non-education undergraduate students of private universities in Enugu Metropolis poor perception of teacher education.

Table 6: ANOVA table showing the difference between mean responses of male and female non-education undergraduates students of private universities in Enugu Metropolis on the extent to which behaviour of some primary and secondary school teachers contributes to their poor perception of teacher Education.

\begin{tabular}{ccclcll}
\hline Source & SS & df & Mean(sq) & F & Sig & decision \\
\hline Gender & 98.41 & 1 & 98.41 & $1.87^{\mathrm{NS}}$ & .172 & Accept Ho2 \\
Error & 18053.48 & 343 & 52.63 & & & \\
Total & 18151.90 & 344 & & & & \\
\hline
\end{tabular}

Note: ${ }^{* * *}=$ Significant, $\mathrm{P}=.000,{ }^{* *}=$ Significant, $\mathrm{P}=.01, \mathrm{NS}=$ Not Significant, $\mathrm{P}=>.05$

ANOVA Result of table 6 showed that the mean difference between male and female responses on the extent to which behaviour of some primary and secondary school teachers contributes to non-education undergraduate students' of private universities poor perception of teacher education was not statistically significant, $F(1,343)=1.87, p>.05$. Therefore, the null hypothesis which states that there is no difference between the mean responses was accepted.

\section{Discussion of the Findings}

The results in Table 1 revealed that out of the eight identified attitudes of primary and secondary school teachers, seven were rated by the respondents as accepted while the remaining one was rejected, with grand mean of 3.3565 which is greater than 3 with standard deviation of 1.361743 . This is an indication that attitude of some primary and secondary school teachers contribute to a large extent to poor perception of teacher education by non-education undergraduate of private universities in Enugu metropolis.

The data on table 1 equally revealed that most of the respondents agreed that most teachers see teaching profession as not being as prestigious as other professions and that most teachers discourage their children from taking up teaching as a profession. These two items numbers 2 and 3 have the highest mean scores of 2, 7420 and 3.7101respectively. This indicates that teachers have poor attitude towards teaching profession in Nigeria. This finding agreed with the finding of Lawal, (2016) that teachers who are the practitioners do not seem to want their 
INTERNATIONAL JOURNAL OF ACADEMIC RESEARCH IN PROGRESSIVE EDUCATION AND DEVELOPMENT

Vol. 7, No. 4, 2018, E-ISSN: 2226-6348 ๑ 2018 HRMARS

children and or wards to choose teaching as a profession. According to him, this might be due to unattractive reward system, low self-esteem among other factors.

However the finding is in contrary to the finding of study carried out in India by Ramakrishnaih (1998) in Debdas and Santosh (2016) that generally, college teachers have a favourable attitude towards teaching and that teachers below 35 years of age have a more favourable attitude towards teaching than the middle age group and the high age group. The finding also did not agree with that of Debdas and Santosh (2016) that the attitude of College teachers in Cooch Behar district of West Bengal India is neither more favourable nor unfavourable towards teaching profession but rather, it depends on the gender and age of teachers. The disagreement in findings may be due to the fact that their studies were done in another country not in Nigeria.

Item 8 on the table was rejected because it has a mean score of 2.2696, which is less than 3 with Standard deviation of 1.55888 . It shows that most respondents disagreed that parents have no regard for teachers. However, standard deviation of 1.55888 revealed that many respondents have divergent view on this point that means that they did not quit agree on this factor.

The observed difference in the mean responses of male and female can be attributed to the fact that women do not bother much about prestigious occupation What they need is an occupation that will give them time to take care of their families.

Regarding the second research question, the data on table 4 reveals the respondents' rating of the extent to which the ten identified behaviour of some primary and secondary school teachers contribute to poor perception of non-education undergraduate students of the private universities in Enugu metropolis to Teacher education. The result showed that all the ten identified factors were rated by the respondents as accepted with a grand mean of 3.5677 and standard deviation of 1.3507. None of the items has mean score of less than 3 . This indicates that some primary and secondary school teachers' behaviour contribute to a great extent to poor perception of non-education undergraduates students of private universities in Enugu metropolis to teacher education. This finding tallies with the findings of Viatonu (2004) in Lawal (2016) that among the problems facing teaching profession in Nigeria are the nature of teachers and the physical appearance of some teachers particularly in primary schools. However the result equally shows that items 9 - has the highest mean scores of 3.8087 with standard deviation (std) of 1.22415, indicating that even among all the items that many respondents were in agreement that incompetent of some teachers in delivering their lessons with the mean scores of 3.7587 and std of 1.31705 contributes to a very high extent to poor perception of students to teacher education. This tends to agree with common notion of people that teaching is for the less intelligence. Some teachers lack professional zeal, qualification and competence. Therefore, with this attribute one can rightly say that some are teachers and some are rather cheats. According to them some teachers became teachers because they could not get employment elsewhere, and leave teaching as soon as they get a greener pasture. This study equally revealed that befriending female students by some male teachers with the mean score of 3.6715 and std of 1.34433 and befriending male students by some female teachers are also contributing factors to poor perception of students of teacher education.

With reference to hypothesis, the result of the null hypothesis in table 4 revealed that there was significant difference between the mean responses of male and female non education undergraduate students of private universities in Enugu metropolis on the extent to which 
Vol. 7, No. 4, 2018, E-ISSN: 2226-6348 @ 2018 HRMARS

attitude of primary and secondary school teachers toward teaching profession contribute to poor perception of non education undergraduate students to teacher education.

The null hypothesis shows that there was is no difference between the mean responses of male and female undergraduates of private universities in Enugu metropolis on the extent to behaviour of primary and secondary school teachers contribute to poor perception of non education undergraduate students to teacher education.

\section{Conclusion}

Based on the results and discussion of this study, it was concluded that attitudes of some primary and secondary school teachers towards teaching profession couple with their unethical behaviour are partly responsible for poor perception of non-education undergraduate students of private universities in Enugu metropolis to teacher education. This explains why non educations undergraduates of private universities are in Enugu metropolis are not interested teaching profession and there look down on their fellow students in the faculty of education.

\section{Recommendations}

1. Teachers at primary and secondary school levels should develop interest in their work and be proud of their profession since they have accepted to engage in it for a living.

2. Teachers should desist from such unethical behaviour that make students and the general public to look down on them as found out in the study. They should not collect money from students and parents to pass students during examination or to allow them engage in examination malpractice. Male teachers should refrain from befriending of female students. Female teachers should also desist from befriending of their male students.

3. Teachers should not see their profession as being inferior to other profession because teaching is a noble profession everybody is taught by teachers, no matter the persons' profession.

4. Primary and secondary school teachers especially those teaching in the rural areas should always dress and comport themselves properly before their students and their parents so that they will be accorded respect.

5. The government and other employers of teachers should try and improve their conditions of service so that they can be proud of their profession and exhibit positive attitude towards teaching to make it attractive.

\section{References}

Anupama, B. and Pathy, M. K. (2014). Attitude of student teachers Towards teaching profession. INDIA Turkish Online Journal of Distance Education-TOJDE July 2014 ISSN 1302-6488 Volume: 15 Number: 3 Article 3

Debdas, S., Santosh, K. B. (2016). Attitude of College Teacher towards Teaching Profession American Journal of educational research, 2016, Vol. 4, No. 11, 834-839 Available online at www.ajer.com.

Elina, S. (2016). Attitude of teachers towards teaching profession Quest Journals; Journal of Research in Humanities and Social Science Volume 4 Issue 6 (2016) pp: 103-105

Ibrahim, M. and Adam, G. B. (2015). Teaching profession in Nigeria: Teacher professionalization is the way out Standard Journal of Educational Research and Essay Vol 3(10) pp. 344-348, 


\section{INTERNATIONAL JOURNAL OF ACADEMIC RESEARCH IN PROGRESSIVE EDUCATION AND}

DEVELOPMENT

Vol. 7, No. 4, 2018, E-ISSN: 2226-6348 @ 2018 HRMARS

Lawal, B. O. (2012). Analysis of parents, Teachers, and students perception of Teaching Profession in Southwest Nigeria. Asian Social Science, 8 (1): 119 - 124.

National Policy on Education (2004). Federal Ministry of Education, National Policy on Education, Lagos, Nigeria.

Odike, T.E. (2015). Attitudes of undergraduates towards the teaching profession in Nigeria (Refernce to Federal Universty, otuoke Bayelsa state Unpublished PDE project. 